\section{Revisiting New Year's Resolutions}

Well, it's that time of year again. We take stock of our progress, note our failures, and basically, start over. This hasn't been an easy year. Between political chaos in Washington, DC, and natural chaos with hurricanes, floods, and fires, it's been pretty distracting. And we can add public shootings and other brutalities to the list of disruptive and disturbing events. It's been scary-even more so if this is the new normal.

But we must remember that, as hard as these things can be for us, we still have a responsibility to reach out to and care for our patients, who have an added layer of fear. Most of our patients benefit from our medicines and other treatments, but cancer can be a vicious beast. I sometimes wonder how my patients put one foot in front of the other, not knowing whether or how long they will survive, not knowing what is around the corner, and not being able to plan.

Last year, I resolved to be a better oncologist. I resolved to care more, listen more, and understand more about other dimensions of their burden, such as financial toxicity. I think I lived up to my promises. But it isn't like I can just check all the boxes and move on. These are practices that we must continue to work on. We practitioners see the same things day in and day out, but we must remember that for the patients, it is the first time. Each patient deserves our genuine concern and empathy. And I realize that, for some of us, burnout is a real phenomenon, so we must take every precaution to avoid it by also taking care of ourselves.

Without a doubt, my list of resolutions for this year will include the resolve to continue being a better oncologist, but I also plan to be a smarter one. I confess that I am content in my own clinical world, where I have the luxury of being surrounded by brilliant folks who are at the top of their field. I can just call them when I have questions. I don't have to work at finding the answers. Well, not any more! I intend to read more, study more, and learn more about other diseases and treatments.

I haven't quite figured out how I will accomplish this. I recall a senior colleague who took a year off and went back to medical school, but I'm not that brave! However, I can attend more lectures and conferences, read my journals cover to cover, and do my own homework when I have a question. That's a start.

If you are reading this, you are probably also thinking about what your own selfimprovement plan will be. At least, I hope you are. If there's one thing I'm certain about, it is that there is always room for improvement. And if you don't have a plan, you'll reach the end of 2018 with nothing to show for it.

So, in closing, I wish you all a very Happy New Year and much luck in meeting all your goals!
What do you think? Please e-mail correspondence (include contact information) to JNCCN@nccn.org or log into www.editiorialmanager.com/JNCCN to submit a Letter to the Editor.

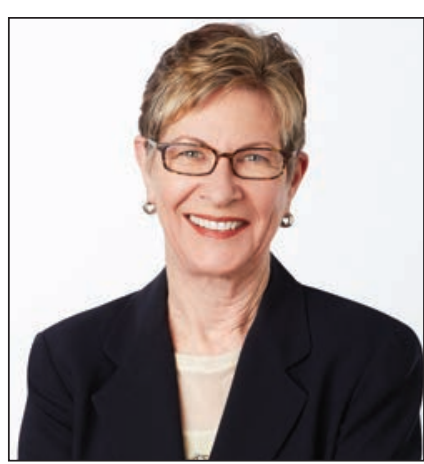

Margaret Tempero, MD

Margaret Tempero, MD, is a Professor of Medicine and Director of the UCSF Pancreas Center and editor-in-chief of JNCCN. Her research career has focused on pancreatic ductal adenocarcinoma, especially in the area of investigational therapeutics. Dr. Tempero has served on the ASCO Board of Directors and as ASCO President. She currently serves on the ASCO Conquer Cancer Foundation Board. She codirected the AACR/ASCO Methods in Clinical Cancer Research and taught this course and similar courses in Europe and Australia. She was founding Chair of the $\mathrm{NCl}$ Clinical Oncology Study Section and served as a member and Chair of the NCl Board of Scientific Counselors Subcommittee $A$. She is a member of the Scientific Steering Committee and Chair of the Clinical and Translational Study Section for the Cancer Prevention \& Research Institute of Texas. She is or has been on the Scientific Advisory Boards of the Lustgarten Foundation, the Pancreatic Cancer Action Network, the $V$ Foundation, The Alberta Canada Cancer Board, and the EORTC. She served as a member of the Oncology Drug Advisory Committee for the FDA. She has served as Deputy Director and Interim Director for the UNMC Eppley Cancer Center. She is Chief Emeritus of the Division of Medical Oncology at UCSF and served as the founding Deputy Director and Director of Research Programs at the UCSF Helen Diller Family Comprehensive Cancer Center.

doi: $10.6004 /$ jnccn.2018.0003

The ideas and viewpoints expressed in this editorial are those of the author and do not necessarily represent any policy, position, or program of NCCN. 